4.

Derecho penal 

Revista de Derecho

de la Pontificia Universidad Católica de Valparaíso XXIX (Valparaíso, Chile, $2^{\text {do }}$ Semestre de 2007)

[pp. 205 - 234]

\title{
EL PATRIMONIO DEL ESTADO COMO OBJETO DE PROTECCIÓN PENAL*
}

\author{
[The State's Patrimony as an Object of Penal Protection]
}

\section{LAura Mayer Lux**}

\begin{abstract}
RESUMEN
Abstract

Este trabajo describe, en primer término, las normas que el ordenamiento jurídico chileno destina a la protección de los intereses patrimoniales del Estado, para analizar, enseguida, el alcance que corresponde atribuir a la noción de patrimonio estatal, en tanto objeto de tutela penal y la forma en que el Derecho penal asume su protección, particularmente en el ámbito de los delitos tributarios y aduaneros, en lo que respecta al fraude de subvenciones y en lo que atañe a algunas figuras tradicionalmente vinculadas con el correcto desempeño de la función pública, como el fraude fiscal y la malversación de caudales públicos.

Palabras clave: Patrimonio del Estado - Patrimonio público - Delitos tributarios - Fraude de subvenciones - Delitos aduaneros - Malversación de caudales públicos - Fraude al Fisco.

The norms that the Chilean legal system destines to the protection of the State's patrimony interests are firstly described in this work. The extent to be ascribed to the notion of state patrimony is analysed, as an object of penal custody and the manner in which the penal law undertakes its protection, especially in the field of tax and customs crimes, regarding subsidy fraud and some figures traditionally linked to the right performance of the public function, as tax fraud and embezzling of public monies.

Keywords: State Patrimony - Public property - Tax crimes - Subvention fraud - Customs crimes - Embezzling of public monies - Fraud to the Treasury.

* Trabajo elaborado en el marco del Proyecto de Investigación FondecyT 1060816, sobre el tema "Protección penal del patrimonio público: estudio dogmático y crítico", desarrollado en la Pontificia Universidad Católica de Valparaíso, bajo la dirección del Profesor Dr. Luis Rodríguez Collao.

** Ayudante de investigación en el proyecto citado en la nota anterior. Dirección postal: Avda. Brasil 2950, Valparaíso, Chile. Correo electrónico: lauramayer@gmx. net
\end{abstract}




\section{INTRODUCCIÓN}

Tradicionalmente, el patrimonio público, como instituto jurídico y, más aún, como interés penalmente tutelado, ha recibido escasa atención por parte de los autores ${ }^{1}$, quienes suelen aludir a él de manera aislada e inorgánica, a propósito de varias figuras delictivas que presentan pocos puntos de conexión entre $s^{i}{ }^{2}$ : nos referimos a los delitos tributarios, al fraude de subvenciones, a los delitos aduaneros e, incluso, a algunos tipos habitualmente ligados al correcto desempeño de la función pública, como la malversación de caudales públicos y el fraude al Fisco, pero cuya vertiente patrimonial es reconocida por la doctrina absolutamente dominante, tanto en Chile, como en el extranjero ${ }^{3}$.

Esta tendencia -más vinculada a nuestra historia legislativa, que a razones puramente dogmáticas-, no se da en otros ordenamientos jurídicos más modernos, que utilizan la noción de patrimonio del Estado como criterio de agrupación de tipos penales ${ }^{4}$. En efecto, para dichas legislaciones, el erario público se presenta como un bien jurídico distinto del patrimonio privado, capaz de reunir en torno a él figuras delictivas diversas, cuyos elementos comunes no han sido suficientemente destacados en nuestra doctrina ${ }^{5}$.

Tomando como base lo antes expuesto, el presente trabajo pretende determinar si el patrimonio público constituye el interés tutelado por esos delitos y, en caso de que la respuesta sea afirmativa, establecer el sentido y el alcance que ha de atribuírsele al mismo.

${ }^{1}$ Las contadas obras que existen sobre el particular analizan el tema desde una perspectiva civil o administrativa, mas no desde una óptica penal, como lo haremos en el presente trabajo. Tal es el caso de Montt Oyarzún, Santiago, Dominio público. Estudio de su régimen especial de protección y utilización (Santiago, ConoSur, 2002).

${ }^{2}$ De ahí, entonces, que su tratamiento se dé en títulos tan disímiles del libro II del Código Penal, como el relativo a los delitos cometidos por empleados públicos en el desempeño de sus cargos o contra la propiedad y, aun, fuera del Código Penal, en el Código Tributario o en la Ordenanza de Aduanas, por mencionar algunos.

${ }^{3}$ Por todos, Rodríguez Collao, Luis - Ossandón Widow, María Magdalena, Delitos contra la función pública (Santiago, Editorial Jurídica de Chile, 2005), p. 372, a propósito de Chile; y Muñoz Conde, Francisco, Derecho penal. Parte especial (Valencia,Tirant lo Blanch, 2004), pp. 1014 y 1015, respecto de España.

${ }^{4}$ Es, entre otros, el caso del ordenamiento penal español, que reúne, en un solo título dedicado a los Delitos contra la Hacienda Pública y contra la Seguridad Social, muchas de las figuras que abordaremos en las páginas siguientes.

${ }^{5}$ En efecto, uno de los pocos autores que ha destacado la vinculación entre las figuras que se analizarán en este trabajo, ha sido Guzmán DÁlbora, José Luis, Estudios y defensas penales (Santiago, LexisNexis, 2005), pp. 211 y 212. 


\section{REGULACIÓN DE LOS DELITOS QUE ATENTAN CONTRA EL PATRIMONIO DEL ESTADO EN EL DERECHO CHILENO}

\section{Los delitos tributarios ${ }^{6}$.}

En Chile, estos delitos están tipificados en el Código Tributario, a través de un conjunto de disposiciones caracterizado por su complejidad y un excesivo casuismo. Como notas comunes a ellos, podemos destacar que las penas corporales aplicables a los mismos son compatibles con sanciones administrativas y civiles; y que dentro de la clasificación de los delitos nos encontraremos con crímenes, simples delitos y faltas ${ }^{7}$. Como rasgo distintivo, en cambio, cabe señalar las particularidades que reviste el sujeto activo ${ }^{8}$, que, en algunos casos, debe ser el contribuyente (artículo 97); en otros, el contador (artículo 100); un funcionario del Servicio de Impuestos Internos (artículo 101); otro funcionario público o municipal (artículo 102); un notario o, aun, un conservador (artículo 103).

a) Maquinaciones fraudulentas. El número 4 del artículo 97 del Código Tributario, a lo largo de sus incisos, castiga diversas conductas en que se disminuye, mediante engaño, el monto del impuesto. El inciso primero sanciona la presentación de declaraciones maliciosamente falsas o incompletas orientadas a liquidar un impuesto inferior al que corresponde, así como todo procedimiento doloso encaminado a ocultar o desfigurar el monto de las operaciones realizadas o a burlar el impuesto ${ }^{9}$. Así, para cometer este delito no es necesario que se produzca el resultado de la

${ }^{6}$ En el presente trabajo analizaremos las figuras que siempre o algunas veces -a discreción del Director del Servicio de Impuestos Internos- constituyen delito según el Código Tributario.

${ }^{7}$ Aste Mejías, Christian, Curso sobre Derecho y Código Tributario (Santiago, LexisNexis, 2006), p. 409.

${ }^{8}$ Según Van Weezel, Alex, Delitos Tributarios (Santiago, Editorial Jurídica de Chile, 2007), p. 15: "Si se trata de sancionar principalmente un perjuicio patrimonial -como parece ser la tendencia de nuestro Código Tributario, agregamos nosotros-, entonces pueden ser autores del hecho todos los que han intervenido en él con cierta intensidad, dominándolo o según lo exijan las diversas concepciones sobre autoría. En cualquier caso, la dependencia de un sujeto con la cualificación personal de «contribuyente» como punto de referencia de la accesoriedad pasa a un segundo plano".

${ }^{9}$ A juicio de Van Weezel, Delitos Tributarios, cit. (n. 8), pp. 15 y 16, en figuras como ésta, el legislador se esfuerza por resaltar el carácter fraudulento, malicioso o "doloso" de ciertas conductas, o bien el hecho de que ha de tratarse de maniobras o maquinaciones al menos destinadas a ocasionar un perjuicio patrimonial al Fisco por medio de la evasión de tributos, y la razón parece ser evidente: "se intenta ofrecer un fundamento plausible para la criminalización de conductas que, consideradas en sí mismas, bien podrían estimarse simples contravenciones". 
evasión, pues basta que existan procedimientos dolosos encaminados a consumarla ${ }^{10}$. Por su parte, el inciso segundo castiga a los contribuyentes afectos al IVA u otros impuestos sujetos a retención o recargo que se valen de procedimientos dolosos para aumentar el monto de sus créditos o imputaciones. Ahora bien, el inciso tercero castiga al que simulando una operación tributaria o valiéndose de cualquier maniobra fraudulenta, obtenga una devolución impositiva ${ }^{11}$. Por último, la Ley No 19.738 agregó un inciso a este artículo, para castigar al que maliciosamente confeccione, venda o facilite, a cualquier título, guías de despacho, facturas, notas de débito, notas de crédito o boletas, falsas, con o sin timbre del Servicio, con el objeto de cometer o posibilitar la comisión de los delitos descritos en este número ${ }^{12}$.

${ }^{10}$ Aste Mejías, Curso, cit. (n. 7), p. 412.

${ }^{11}$ Según Ugalde Prieto, Rodrigo - García Escobar, Jaime, Curso sobre delitos e infracciones tributarias (Santiago, LexisNexis, 2005), p. 29, este tipo se configura a partir del resultado, ya que exige que la devolución indebida se hubiere obtenido. Aquí, la pena es de presidio menor en su grado máximo a presidio mayor en su grado medio y multa del cien por ciento al cuatrocientos por ciento de lo defraudado, castigo que ha llevado a estos mismos autores, en la p. 30 de la obra citada, a señalar que "en modo alguno se justifica una sanción de la magnitud que establece el tipo penal en estudio [...], esto es, desde tres años y un día a quince años. Sin duda, el bien jurídico protegido por este delito es de alta relevancia, pero creemos que ello no permite explicar esta penalidad, especialmente si la comparamos con la del homicidio simple [...]; vale decir, pareciera ser que para el legislador poseería la misma entidad e importancia el patrimonio del Fisco que el bien jurídico vida, aserto que evidentemente no es efectivo...".

${ }^{12}$ A propósito de este delito y, en relación al interés tutelado, el Tribunal de Juicio Oral en lo Penal de Ovalle, en sentencia de 6 de diciembre de 2005, resolvió que aquél constituía un delito formal, en el que basta para su configuración que el sujeto incurra en uno o más de los verbos rectores que lo integran (confeccionar, vender o facilitar la documentación tributaria falsa), en forma "maliciosa", esto es, "dolosa" o "intencional", y con el objeto de cometer alguno de los tres delitos que consagra el número 4 del artículo 97 del Código Tributario, o hacer posible su ejecución, no siendo necesario que se cause efectivamente un perjuicio a la Hacienda Pública, ni que se produzca un resultado o efecto material determinado, diverso al actuar prohibido del sujeto activo. En esa ocasión, el tribunal estableció que se trataba de un delito de peligro abstracto, en el que el daño efectivo del bien jurídico protegido (patrimonio fiscal) no es un elemento exigido por el tipo y, por lo mismo, no admite las formas imperfectas de ejecución (tentativa y frustración) (Tribunal de Juicio Oral en lo Penal de Ovalle, de 6.12.05. Sentencia condenatoria, "SII c/ Jorge Patricio Castillo Maluenda y otro", rol No 81-04). Además, respecto del tipo en comento, la Corte de Apelaciones de Valdivia, en fallo de 19 de octubre de 2004, resolvió que es de justicia fijar la pena de multa en una suma que tenga alguna relación con el daño fiscal causado por los delitos investigados (Corte de Apelaciones de Valdivia, 
El numeral 5 del artículo 97 consagra una figura que podemos catalogar de omisión propia, ya que sanciona: "la omisión maliciosa de declaraciones exigidas por las leyes tributarias para la determinación o liquidaciones de un impuesto, en que incurran el contribuyente o su representante, y los gerentes y administradores de personas jurídicas o los socios que tengan el uso de la razón social [...] "13. Nuevamente, se exige una conducta maliciosa, esto es, que se incurra en la omisión indicada con el propósito de privar al Fisco de la percepción de tributos que legítimamente le corresponden ${ }^{14}$.

Por su parte, el numeral 10 del artículo 97 del Código Tributario castiga la reiteración en el no uso o en el mal uso de documentos, en especial, en caso de no otorgar guías de despacho, facturas, notas de débito, notas de crédito o boletas en los casos y en la forma exigidos por la ley; de usar boletas no autorizadas o guías de despacho, facturas, notas de débito o notas de crédito sin el timbre correspondiente; o bien, de fraccionar el monto de las operaciones para eludir el otorgamiento de boletas ${ }^{15}$.

El número 22 del artículo 97 contiene una alusión directa al interés tutelado, ya que castiga al "que maliciosamente utilizare los cuños verdaderos u otros medios tecnológicos de autorización del Servicio para defraudar al Fisco". Del precepto transcrito destaca, a simple vista, que la conducta debe llevarse a cabo maliciosamente y con el propósito de defraudar al Fisco, esto es, con el fin de producir a éste un perjuicio patrimonial.

El número 23 del artículo 97 del Código Tributario penaliza dos figuras: el inciso primero del referido precepto sanciona al que maliciosamente proporcione datos o antecedentes falsos en: i) La declaración inicial de actividades; ii) Las modificaciones a la declaración inicial de actividades; iii) Las declaraciones exigidas con el objeto de obtener autorización de documentación tributaria, incluyendo todas las declaraciones requeridas para cumplir el trámite de timbraje de documentos; y, en el inciso segundo, impone una pena si se reúnen los siguientes requisitos copulativos: i) Que se faciliten los medios para que el contribuyente, en las declaraciones de inicio de actividades, sus modificaciones o en las declaraciones exigidas

de 19.10.04, Recurso de apelación, “SII c/ Jorge Patricio Cabrera Marín”, rol No 2.034-04).

${ }^{13}$ La tipificación de figuras omisivas es invocada como argumento a favor de que los delitos -en este caso, tributarios- se conciban como supuestos de infracción de deber, pues en los tipos omisivos, no se castiga un hacer, sino la infracción de un deber específico (de contribuir). En esa línea, a propósito de la malversación, CASTRO Moreno, Abraham, La malversación de caudales en el Código Penal de 1995 (Valencia, Tirant lo blanch, 2001), p. 31.

${ }^{14}$ Ugalde Prieto - García Escobar, Curso, cit. (n. 11), p. 12.

${ }^{15}$ Para estos efectos, se entenderá que hay reiteración cuando se cometan dos o más infracciones entre las cuales no medie un período superior a tres años. 
para obtener autorización de documentación tributaria, hubiere incluido maliciosamente datos o antecedentes falsos; y ii) Que exista concierto entre quien presenta los antecedentes y quien los facilita.

Finalmente, el artículo 100 del Código Tributario castiga al contador que, al confeccionar o firmar cualquier declaración o balance, o que como encargado de la contabilidad de un contribuyente, incurra en falsedad o actos dolosos. Probablemente, la indeterminación de la conducta en el sentido de exigir "que se incurra en falsedad o actos dolosos" ha llevado a que algunos exijan que sea realizada en perjuicio del Fisco ${ }^{16}$.

b) Quebrantamiento de medidas conservativas y de sanciones. El número 12 del artículo 97 sanciona: "la reapertura de un establecimiento comercial o industrial o de la sección que corresponda, con violación de una clausura impuesta por el Servicio”. En esa línea, el numeral 13 del mismo artículo castiga "la destrucción o alteración de los sellos o cerraduras puestos por el Servicio, o la realización de cualquiera otra operación destinada a desvirtuar la aposición de sellos o cerraduras".

De otro lado, el número 14 del artículo 97 del Código Tributario sanciona, en primer lugar: "la sustracción, ocultación o enajenación de especies que queden retenidas en poder del presunto infractor, en caso de que hayan adoptado medidas conservativas [...]" y, enseguida, con la misma pena de la conducta anterior: "al que impidiere en forma ilegítima el cumplimiento de la sentencia que ordene el comiso".

c) Actividad económica informal. El artículo 97 número 8 del Código Tributario castiga supuestos en que se ejerce el comercio sin dar cumplimiento a las exigencias legales ${ }^{17}$. A propósito del ejercicio del comercio, el numeral 9 del referido artículo sanciona: "el ejercicio efectivamente clandestino del comercio o de la industria”.

El numeral 18 del artículo 97 del Código Tributario castiga a: "los que compren y vendan fajas de control de impuestos o entradas a espectáculos públicos en forma ilícita"; mientras que su numeral 26 sanciona la venta o abastecimiento clandestinos de gas natural comprimido o gas licuado de petróleo para consumo vehicular.

d) Abuso de franquicias y beneficios tributarios. En fin, el numeral 24 del tantas veces citado artículo 97 del Código Tributario castiga al contribuyente de la Ley de Impuesto a la Renta que recibe dolosa o reiteradamente contraprestaciones por donaciones con beneficio tributario;

\footnotetext{
${ }^{16}$ Aste Mejías, Curso, cit. (n. 7), p. 440.

${ }^{17} \mathrm{El}$ numeral 8 del artículo 97 del Código Tributario sanciona "El comercio ejercido a sabiendas sobre mercaderías, valores o especies de cualquiera naturaleza sin que se hayan cumplido las exigencias legales relativas a la declaración y pago de los impuestos que graven su producción o comercio [...]”.
} 
o bien, que simula reiterada y dolosamente una donación con beneficio tributario. Asimismo, sanciona a quien destina o utiliza dolosamente donaciones con beneficio tributario a fines no estatutarios de la entidad donataria; y, tratándose de contribuyentes del Impuesto de Primera Categoría de la Ley de Impuesto a la Renta, castiga el comportamiento de deducir dolosa y reiteradamente como gasto donaciones que la ley no permite deducir.

Finalmente, el numeral 25 del artículo 97 del Código Tributario contiene una referencia expresa al perjuicio fiscal. En efecto, el inciso primero de dicha disposición sanciona al que actúe como usuario de las Zonas Francas establecidas por ley, sin tener la habilitación correspondiente o, teniéndola, la haya utilizado con la finalidad de defraudar al Fisco. Por su parte, el inciso segundo de dicha norma castiga con la misma pena a quien efectúe transacciones con una persona que actúe como usuario de las Zonas Francas, sabiendo que no cuenta con la habilitación correspondiente o, teniéndola, la utiliza con el fin de defraudar al Fisco.

e) Delitos tributarios que pueden cometer funcionarios del Servicio, otros funcionarios públicos o municipales, notarios, conservadores, archiveros y otros ministros de fe. El artículo 101 del Código Tributario establece diversas infracciones que pueden cometer los funcionarios del Servicio de Impuestos Internos. En concreto, pueden ser sancionados por: i) Atender profesionalmente a los contribuyentes en cuanto diga relación con la aplicación de las leyes tributarias ${ }^{18}$; ii) Permitir o facilitar a un contribuyente el incumplimiento de las leyes tributarias; iii) Ofrecer su intervención en cualquier sentido para reducir la carga tributaria de un contribuyente o para liberarle, disminuirle o evitar que se le aplique una sanción; iv) Obstaculizar injustificadamente la tramitación o resolución de un asunto o cometer abusos comprobados en el ejercicio de su cargo; y, en fin, v) Infringir la obligación de guardar el secreto de las declaraciones en los términos señalados en el Código Tributario.

A su vez, el artículo 102 del referido Código, recurriendo a una fórmula absolutamente imprecisa de la conducta típica, castiga con multa a todo funcionario ${ }^{19}$ que falte a las obligaciones que le impone este Código o las leyes tributarias, pena que aumenta en caso de reincidencia y que es "sin perjuicio de las demás sanciones que puedan aplicarse de acuerdo con el estatuto que rija sus funciones".

${ }^{18}$ Excepto la atención profesional que puedan prestar a sociedades de beneficencia, instituciones privadas de carácter benéfico y, en general, fundaciones o corporaciones que no persigan fines de lucro.

${ }^{19}$ Sea fiscal o municipal o de instituciones o empresas públicas, incluyendo las que tengan carácter fiscal, semifiscal, municipal o de administración autónoma. 
El artículo 103 del mismo Código establece que notarios, conservadores, archiveros y otros ministros de fe que infrinjan las obligaciones que les imponen las leyes tributarias, serán sancionados "en la forma prevista en dichas leyes".

Finalmente, el artículo 104 del Código Tributario hace aplicables las mismas sanciones previstas en los artículos 102 y 103 a las personas en ellos mencionadas que infrinjan las obligaciones relativas a exigir la exhibición y dejar constancia de la cédula del rol único tributario o del certificado provisorio, en aquellos casos previstos en el Código Tributario, en el reglamento del rol único tributario o en otras disposiciones tributarias ${ }^{20}$.

\section{El fraude de subvenciones.}

Este delito fue incorporado a nuestro Código Penal en 1980, por el Decreto Ley No 3.443, mediante la adición de un nuevo numeral -el 8-al artículo 470, sancionando así, con las penas del artículo 467 del citado Código: "a los que fraudulentamente obtuvieren del Fisco, de las municipalidades, de las cajas de previsión y de las instituciones centralizadas o descentralizadas del Estado, prestaciones improcedentes, tales como remuneraciones, bonificaciones, subsidios, pensiones, jubilaciones, asignaciones, devoluciones o imputaciones indebidas" ${ }^{21}$. Para Politoff, Matus y Ramírez, la introducción de este numeral encuentra su fundamento en la creciente importancia de las subvenciones de todo tipo administradas por el Estado, si bien

${ }^{20}$ Respecto de los notarios, el artículo 78 inciso primero del Código Tributario contempla una responsabilidad adicional, al señalar que éstos tendrán la obligación de vigilar el pago del tributo que corresponda a cada documento que autoricen o protocolicen, en relación con los impuestos de la Ley de Timbres y Estampillas, siendo solidariamente responsables del pago de los mismos, sin perjuicio de lo dispuesto en el artículo 158. Según Aste Mejías, Curso, cit. (n. 7), p. 445: "Dicha responsabilidad cesa si el impuesto hubiere sido enterado en arcas fiscales, de acuerdo con la determinación que hiciere la justicia ordinaria, de conformidad al artículo 158. En consecuencia, los notarios son solidariamente responsables de los tributos anteriormente citados, en caso de que éstos no hayan sido enterados por las personas obligadas al pago. Es ésta una responsabilidad excepcional que la ley ha contemplado respecto de esos funcionarios, y no cabe, por tanto, hacerla efectiva en los conservadores, archiveros y otros ministros de fe".

${ }^{21}$ Cabe hacer presente, que este mismo Decreto Ley incorporó, al Código Tributario, el tipo del inciso tercero del número 4 del artículo 97 . Ahora bien, la pena más grave aplicable al delito del número 8 del artículo 470 del Código Penal, es la de presidio menor en su grado medio a máximo, sugiriendo que, para el legislador, posee un mayor disvalor obtener devoluciones indebidas de impuestos que obtener devoluciones del Fisco que tengan otro origen. Para Ugalde Prieto - García Escobar, Curso, cit. (n. 11), p. 30, "ésta no parece una razón suficiente, que justifique la disparidad en la sanción en uno y en otro caso”. 
su actual redacción no sería sino una especificación de la regla general, que reconoce expresamente las dos formas de disposición patrimonial: la entrega efectiva, en los casos en que se obtienen fraudulentamente tales remuneraciones, devoluciones, etc.; y la renuncia al cobro, en los casos en que fraudulentamente se realizan "imputaciones indebidas" fuera de la regulación contemplada en el Código Penal, el catálogo de leyes que contienen supuestos especiales de fraudes de subvenciones es extenso y variado. En efecto, se trata ésta de una figura presente en una serie de leyes que otorgan beneficios tributarios ${ }^{23}$, aduaneros ${ }^{24}$, de fomento ${ }^{25}$, etc., caracterizadas, muchas de ellas, por reducir el engaño exigido para la defraudación a la simple presentación de datos falsos para obtenerlas, su ocultamiento u otras modalidades semejantes; por alterar, además, la pena aplicable, no vinculándola al monto de lo defraudado ${ }^{26}$; y aun, eliminando el requisito del perjuicio ${ }^{27}$, transformando el delito en uno consistente en la sola entrega de documentos o datos falsos, el ocultamiento de los verdaderos u otros semejantes, pero sin esperar la producción de un daño en el patrimonio fiscal para entenderlos consumados ${ }^{28}$.

\section{Los delitos aduaneros.}

El libro III de la Ordenanza de Aduanas $^{29}$ regula las infracciones a la misma, sus penas y el procedimiento para aplicarlas. En el título $1^{\circ}$,

${ }^{22}$ Politoff, Sergio - Matus, Jean Pierre - Ramírez, María Cecilia, Lecciones de Derecho penal chileno. Parte especial (Santiago, Editorial Jurídica de Chile, 2004), p. 448.

${ }^{23}$ Así, la Ley No 18.634, cuyos artículos 29 y 30 establecen un sistema de pago diferido de derechos de aduana, crédito fiscal y otros beneficios de carácter tributario que indica.

${ }^{24}$ En ese sentido, los artículos 6 y 7 de la Ley No 18.708, que establece un sistema de reintegro de derechos y demás gravámenes aduaneros que indica en favor de los exportadores.

${ }^{25}$ Por ejemplo, el artículo 35 inciso décimo de la Ley No 19.420, que establece incentivos para el desarrollo económico de las Provincias de Arica y Parinacota.

${ }^{26}$ Así, el Decreto con Fuerza de Ley No 150, de 1982, que fija el texto refundido, coordinado y sistematizado de las normas sobre sistema único de prestaciones familiares y sistema de subsidios de cesantía para los trabajadores del sector primario y público; o la Ley No 19.728, cuyo artículo 27 establece un seguro de desempleo.

${ }^{27}$ En esa línea, la Ley No 18.229 , cuyo artículo 5 concede una asignación por contratación adicional de mano de obra.

${ }^{28}$ Politoff - Matus - Ramírez, Lecciones, cit. (n. 22), pp. 448 y 449.

${ }^{29}$ En el Anteproyecto de Código Penal Chileno, de 2005, elaborado por la Comisión Foro Penal., Polit. crim. no 1, D1, pp. 1-92, en cambio, los delitos aduaneros, como los tributarios, se regulan directamente en el Código Penal (artículos 331 a 334). 
contempla las disposiciones generales (artículos 168 a 172), las contravenciones aduaneras y sus sanciones (artículos 173 a 177), el contrabando y el fraude (artículos 178 a 182) ${ }^{30}$, así como el comiso administrativo de la mercancía (artículo 183). En el título $2^{\circ}$, dedicado a la fiscalización y al procedimiento, consagra las disposiciones generales (artículos 184 a 187) y las relativas al contrabando y al fraude (artículos 188 a 190).

Ahora bien, en lo tocante a los delitos contemplados en dicho cuerpo normativo, el inciso segundo del artículo 168 define el contrabando, estableciendo que incurrirá en este delito: "el que introduzca al territorio nacional, o extraiga de él, mercancias cuya importación o exportación, respectivamente, se encuentren prohibidas. Comete también el delito de contrabando ${ }^{31}$ el que, al introducir al territorio de la República, o al extraer de él, mercancias de lícito comercio, defraude la Hacienda Pública mediante la evasión del pago de los tributos que pudieren corresponderle o mediante la no presentación de las mismas a la Aduana. Asimismo, incurre en el delito de contrabando ${ }^{32}$ el que introduzca mercancias extranjeras desde un territorio de régimen tributario especial a otro de mayores gravámenes, o al resto del pais, en alguna de las formas indicadas [...]". Fuera del contrabando, la Ordenanza de Aduanas, en su artículo 169, sanciona otras conductas, como: "la declaración maliciosamente falsa del origen, peso, cantidad o contenido de las mercancias de exportación”; así como a "quienes falsifiquen material o ideológicamente certificaciones $o$ análisis exigidos para establecer el origen, peso, cantidad o contenido de las mercancias de exportación”. De otro lado, el artículo 178 dispone que las penas aplicables a los delitos de contrabando y fraude son:

${ }^{30}$ Dichas normas, más que establecer conductas, se ocupan de señalar las penas aplicables a las mismas; y disponen que los delitos de contrabando y fraude "se castigarán como consumados desde que se encuentren en grado de tentativa". A propósito de esto último, la Corte Suprema ha dicho: "No puede absolverse a los encausados fundándose en no haber existido perjuicio para el Estado, por cuanto los delitos por los que se les acusa se castigan como consumados desde que se encuentren en grado de tentativa" (Corte Suprema, rol No 33.464-96, fallada el 14 de noviembre de 1996).

${ }^{31}$ La Ley No 19.738, de 19 de junio de 2001, introdujo reformas, entre otros cuerpos legales, a la Ordenanza de Aduanas. La idea del legislador fue refundir en un solo tipo las figuras de fraude y contrabando. Bajo esta última denominación, se configura el contrabando propiamente tal (primera parte de la disposición), con verdaderas figuras de fraude bajo la forma de contrabando impropio que se describen en la segunda y tercera parte de la definición. De ello se evidencia el claro propósito del legislador de mantener la figura de fraude aduanero, toda vez que los elementos del tipo corresponden a ella, subsumida bajo el nombre de contrabando, pero además, bajo la forma de delito de resultado y no de peligro, como se desprendía del texto anterior (Corte de Apelaciones de Valparaíso, rol No 9.275-02, fallada el 10 de diciembre de 2003).

${ }^{32}$ Ibídem, cit. (n. 31). 
"sin perjuicio de la responsabilidad que pueda caber a los funcionarios aduaneros, de acuerdo con lo dispuesto en el artículo 239 del Código Penal (fraude al Fisco) y de la que corresponda a otros que hayan tenido participación en ellos $^{\prime 33}$. Por último, los artículos 179 a 182 de la Ordenanza de Aduanas establecen una serie de presunciones relativas a los delitos de contrabando y fraude, cuya vigencia resulta bastante cuestionable si somos respetuosos del principio de presunción de inocencia ${ }^{34}$.

\section{La malversación de caudales públicos.}

El delito de malversación se encuentra regulado en el párrafo $5^{\circ}$ del título $5^{\circ}$ del libro II del Código Penal, en los artículos 233 y siguientes.

Ahora bien, los artículos 233 y 234 regulan la forma más grave de esta figura, que se acostumbra a denominar peculado. La primera de estas normas castiga al "empleado público que, teniendo a su cargo caudales o efectos públicos o de particulares en depósito, consignación o secuestro, los substrajere o consintiere que otro los substraiga", con una pena que se gradúa según la cuantía de la substracción. La segunda, por su parte, contiene la forma culposa de esta infracción, pues sanciona al "empleado público que, por abandono o negligencia inexcusables, diere ocasión a que se efectúe por otra persona la substracción de caudales o efectos públicos o de particulares de que se trata en los tres números del artículo anterior", quedando el autor obligado a la devolución de lo substraído, además de la pena señalada. El objeto material del delito son caudales o efectos públicos o de particulares, que

${ }^{33}$ Los términos amplios del artículo 239 del Código Penal se emplearon precisamente para comprender en ellos no sólo los casos especificados en el Código español "sino a los vistas y demás empleados de la Aduana que hacen un aforo falso de las mercaderías, o permiten internarlas sin ser depositadas en Aduana o de cualquier otro modo dañan los intereses fiscales que tienen a su cargo" (Actas de la Comisión Redactora del Código Penal, sesión de 13 de julio de 1873).

${ }^{34}$ Prado Casas, Benjamín - Elizalde Aldunate, Ramón, Ordenanza de Aduanas. Anotada, comentada y concordada (Santiago, 2005, LexisNexis), p. 154. En ese orden de ideas, Carocca Pérez, Álex, El nuevo sistema procesal penal (Santiago, LexisNexis, 2005), pp. 14 y 15 y 95 ss., según quien: "La presunción de inocencia es la garantía que preside la aplicación del nuevo proceso penal, porque precisamente el que toda sentencia deba ser producto de un proceso previo legalmente tramitado, obliga a que mientras él no concluya la persona sea tenida como inocente para todos los efectos legales. La garantía de la presunción de inocencia se encuentra claramente acogida a nivel internacional en el artículo 14.2 del Pacto Internacional de Derechos Civiles y Políticos [...], y en la Convención Americana sobre Derechos Humanos [...]. Acogiendo por primera vez en forma clara este mandato constitucional, el nuevo Código Procesal Penal dispone expresamente que «Ninguna persona será considerada culpable ni tratada como tal en tanto no fuere condenada por una sentencia firme» (artículo 4 CPP.)." 
se encuentren a cargo del empleado público por razón de su cargo ${ }^{35}$.

Por su parte, el artículo 235 del Código Penal castiga la distracción o uso indebido de caudales o efectos públicos, figura que se conoce como desfalco cuando la distracción se refiere a dinero ${ }^{36}$, que impone una pena, considerablemente menor a la del peculado, al empleado público que aplicare a usos propios o ajenos los caudales o efectos puestos a su cargo, y de manera diversa, según haya habido o no daño o entorpecimiento del servicio público; pero con las penas del artículo 233 si no se verifica reintegro ${ }^{37}$.

De otro lado, el artículo 236 del Código Penal castiga al empleado público que arbitrariamente diere a los caudales o efectos que administra una aplicación pública diferente de aquella a que estuvieren destinados, figura que también distingue, para aplicar la pena, según si se ha producido o no dańo o entorpecimiento para el servicio u objeto en que debían emplearse, y que corresponde al concepto clásico de malversación, entendida como "inversión indebida" o "desviación de fondos públicos"38.

Por último, el artículo 237 del Código Penal castiga la negativa a un pago o entrega, conducta que se asimila a la malversación, pero que en estricto rigor constituye una figura de mera desobediencia de órdenes de la autoridad.

\section{El fraude al Fisco.}

El artículo 239 del Código Penal sanciona al "empleado público que en las operaciones en que interviniere por razón de su cargo, defraudare o consintiere que se defraude al Estado, a las municipalidades o a los establecimientos públicos de instrucción o beneficencia, sea originándoles pérdida $o$ privándoles de un lucro legitimo", con la pena de presidio menor en sus grados medio a máximo, inhabilitación especial perpetua para el cargo $\mathrm{u}$ oficio y multa del diez al cincuenta por ciento del perjuicio causado. El perjuicio ocasionado al Fisco puede consistir en pérdidas directas o en la privación de un lucro legítimo o cesante ${ }^{39}$ y de él dependerá el valor de la pena pecuniaria que se aplique.

En el presente trabajo no analizaremos otros tipos del título $5^{\circ} \mathrm{del}$ libro I del Código Penal que también podrían vincularse con el patrimonio público, aunque no de modo tan cercano como las figuras de malversación

${ }^{35}$ Etcheberry, Alfredo, Derecho penal. Parte especial (Santiago, Editorial Jurídica de Chile, 1997), IV, p. 239.

${ }^{36}$ Politoff - Matus - Ramírez, Lecciones, cit. (n. 22), p. 497.

${ }^{37}$ Etcheberry, Derecho penal, cit. (n. 35), IV, pp. 240 y 241.

${ }^{38}$ Rodríguez Collao - Ossandón Widow, Delitos, cit. (n. 3), p. 367.

${ }^{39}$ Politoff - Matus - Ramírez, Lecciones, cit. (n. 22), p. 498. 
y fraude, de las que sí nos ocupamos. Sin perjuicio de ello, resulta a este respecto destacable el tipo de negociación incompatible del artículo 240 del referido Código, que castiga al "empleado público que directa o indirectamente se interese en cualquier clase de contrato u operación en que debe intervenir por razón de su cargo"; tipo que también se configura si en el negocio u operación confiados a su cargo diere interés a su cónyuge o a los parientes que la norma especifica ${ }^{40}$. O bien, el delito de enriquecimiento ilícito del artículo 241 bis del Código Penal, que castiga con multa equivalente al monto del incremento patrimonial indebido y con la pena de inhabilitación absoluta temporal para el ejercicio de cargos y oficios públicos en sus grados mínimo a medio al "empleado público que durante el ejercicio de su cargo obtenga un incremento patrimonial relevante e injustificado [...]" ${ }^{\text {"40. }}$.

\section{El tráfico de influencias en el Anteproyecto de Código Penal.}

Cabe mencionar, por último, la regulación que el Anteproyecto de Código Penal de 2005 prevé para el delito de tráfico de influencias, en el Párrafo inmediatamente posterior al de la malversación. En efecto, aunque no consideramos dicha figura dentro de los delitos que atentan contra los intereses patrimoniales del Estado, en atención a la regulación que actualmente le otorga nuestro Código Penal ${ }^{41}$, muy vinculada a la función pública, la propuesta de la Comisión Foro Penal, si bien lo conserva dentro del Título de los Delitos contra la Administración Pública, en el artículo 261, le asigna la siguiente redacción: "[el] "funcionario público que, prevaliéndose de las facultades de su cargo o de cualquier otra situación derivada de su relación personal o jerárquica, ejerza influencia en otro funcionario para obtener una

${ }^{40}$ Esta figura, más que imputar un determinado comportamiento, castiga un simple estado de cosas, que puede originarse en la comisión de cualquier delito -v. gr., tráfico ilícito de estupefacientes, cohecho, etc.- y no sólo de un comportamiento contrario a los intereses fiscales.

${ }^{41}$ Así, fuera de lo dispuesto en las normas relativas al cohecho -la otra figura a la cual se vincula el delito de tráfico de influencias-, el artículo 240 bis señala que las penas establecidas en el artículo precedente (sobre negociación incompatible) serán también aplicadas al "empleado público que, interesándose directa o indirectamente en cualquier clase de contrato u operación en que deba intervenir otro empleado público, ejerciere influencia en éste para obtener una decisión favorable a sus intereses". El inciso segundo, por su parte, señala que "las mismas penas se impondrán al empleado público que, para dar interés a cualquiera de las personas expresadas en los incisos tercero y final del articulo precedente, en cualquier clase de contrato u operación en que deba intervenir otro empleado público, ejerciere influencia en él para obtener una decisión favorable a esos intereses". Por último, el inciso final dispone que "en los casos a que se refiere este artículo, el juez podrá imponer la pena de inhabilitación absoluta perpetua para cargos u oficios públicos". 
decisión favorable a sus intereses o de un tercero [...]". Y con una pena mayor, que depende del monto del perjuicio causado, si perjudica al Estado, utilizando, de esta forma, la lesión a los intereses patrimoniales del Fisco como elemento central a la hora de determinar la penalidad aplicable.

\section{LA PROTECCIÓN DEL PATRIMONIO DEL ESTADO EN EL ORDENAMIENTO JURÍDICO-PENAL CHILENO}

\section{Los delitos tributarios.}

En materia de delitos tributarios, la protección de los intereses patrimoniales del Estado puede sustentarse en argumentos de la más diversa índole, a saber: en el hecho de que algunas figuras establezcan, dentro de la descripción típica, alusiones expresas al perjuicio fiscal, como el número 22 del artículo 97 del Código Tributario, que exige que la conducta se realice "para defraudar al Fisco"; o el numeral 25 del artículo 97 del mismo cuerpo normativo, que requiere que la acción se ejecute "con la finalidad de defraudar al Fisco" ${ }^{\text {"2. }}$. Asimismo, en la circunstancia de que los delitos tributarios más importantes -como los de los incisos primero, segundo y tercero del número 4 y el numeral 5 del artículo 97 del Código Tributario- impongan una sanción corporal que aparece íntima e indisolublemente vinculada a una pena pecuniaria y hace depender el castigo del valor del tributo eludido ${ }^{43}$ e, igualmente, en que se señale que, en los procesos criminales generados por infracción a las normas tributarias, será causal atenuante de responsabilidad penal "la circunstancia de que el hecho punible no haya acarreado perjuicio al interés fiscal, como también el haberse pagado el impuesto debido, sus intereses y sanciones pecuniarias" (artículo 111 del Código Tributario ${ }^{44}$.

${ }^{42}$ El Servicio de Impuestos Internos, en Circular No 26, de 3 de junio de 2004, ha dicho que: "al usar el legislador la expresión "con la finalidad de defraudar al Fisco", está aludiendo a un elemento subjetivo que indica que el sujeto activo del delito actúa con un ánimo preconcebido de lesionar patrimonialmente al Fisco. En tal sentido, para entender configurada la infracción se requiere demostrar que el sujeto activo ejecutó actos que incidieron directamente en un perjuicio del interés fiscal o, por lo menos, que los actos ejecutados estaban destinados a ello, aun cuando la acción no haya arribado a ese resultado. El perjuicio al interés fiscal, en todo caso, debe relacionarse con una lesión a la tributación fiscal interna y cuya fiscalización sea, de acuerdo con la ley, de competencia de este Servicio de Impuestos Internos".

${ }^{43}$ Vallejos Castro, Eduardo, La prueba en el delito tributario (Santiago, Editorial Jurídico-Tributaria S.A., 1988), p. 62.

${ }^{44}$ Así, el artículo 107 del Código Tributario establece que las sanciones que el Servicio imponga se aplicarán dentro de los márgenes que correspondan, tomando en consideración, entre otras circunstancias, "el perjuicio fiscal que pudiere derivarse de la infracción”. 
A los argumentos expuestos se agregan las múltiples normas dedicadas a regular los medios de fiscalización del cumplimiento de las obligaciones tributarias, todas las cuales, giran en torno a la idea de asegurar al máximo el pago del tributo, esto es, la obligación tributaria principal ${ }^{45}$, cuyo incumplimiento ha sido sindicado, por algunos autores, como la "esencia" de este grupo de delitos ${ }^{46}$.

Asimismo, se incluyen ciertas normas en materia procesal penal, especialmente aquellas que establecen los criterios de actuación relativos a los acuerdos reparatorios, según las cuales, los fiscales "evaluarán con detención su procedencia y conveniencia" respecto de los delitos tributarios (y aduaneros) -en vez de "favorecerán", como ocurre con los delitos contra la propiedad privada-, exigencia que, a nuestro juicio, encuentra su justificación en que lo protegido por estas figuras excede el concepto de "bien jurídico disponible de carácter patrimonial" y se identifica con un interés colectivo de gran trascendencia: el patrimonio público y la actividad financiera estatal ${ }^{47}$.

\section{El fraude de subvenciones.}

En cambio, la forma que asume la protección del patrimonio público en el fraude de subvenciones varía mucho según nos ubiquemos en la regulación que establecen leyes especiales o el propio Código Penal. En efecto, respecto de las primeras, resulta bastante forzado sostener que los intereses patrimoniales del Estado constituyen el interés lesionado o preponderantemente afectado por esta figura, debido a que muchas de las hipótesis previstas en la legislación penal especial eliminan, derechamente,

No obstante, en el artículo 330 del Anteproyecto de Código Penal Chileno de 2005, elaborado por la Comisión Foro Penal. Polit. crim. No 1, D1, pp. 1-92, se elimina la primera parte de la disposición, alusiva al perjuicio al interés fiscal, y se señala, solamente, que "para los efectos de este párrafo, constituirá circunstancia atenuante de responsabilidad penal la de haberse pagado el impuesto debido, sus intereses y las eventuales sanciones administrativas".

${ }^{45}$ Aste Mejías, Curso, cit. (n. 7), p. 82.

${ }^{46}$ Así, Ferreiro Lapatza, José Juan, Curso de Derecho Financiero Español (Barcelona, Marcial Pons, 2006), pp. 564 y 565, según quien, el bien jurídico en un delito que consiste, en esencia, en no pagar tributos, es, obviamente el tributo que debe pagarse y no se paga, o, lo que es lo mismo, la Hacienda Pública en sentido patrimonial.

${ }^{47}$ Oficio No 38, de 21 de enero de 2003, emitido por el Fiscal Nacional del Ministerio Público y dirigido a los Fiscales Regionales y fiscales adjuntos del país, que introduce modificaciones y fija el texto refundido y sistematizado del Instructivo General No 34, sobre criterios de actuación relativos a los acuerdos reparatorios. Dicha normativa, fuera de reconocer que el bien jurídico tiene, efectivamente, un carácter patrimonial, lo sitúa en un nivel distinto del patrimonio particular. 
la exigencia del perjuicio fiscal para alcanzar la consumación, o dejan de vincular la pena aplicable al monto de lo defraudado. Estas características, que muchas veces no obedecen sino al afán de dotar de mayor eficacia a la persecución de dichas conductas, contrastan con el hecho indiscutible de que en el Código Penal, lo sancionado por esta figura es el actuar de quien, fraudulentamente, "obtuviere del Fisco, de las municipalidades, de las cajas de previsión y de las instituciones centralizadas o descentralizadas del Estado, prestaciones improcedentes" (número 8 del artículo 467 del Código Penal).

Dicha consideración se ve reforzada por la regulación que de la materia contempla el Anteproyecto de Código Penal de 2005, que, en un párrafo especial (el noveno), dentro del título $13^{\circ}$ del libro II, denominado De la obtención indebida de prestaciones económicas estatales, mantiene la figura en los términos actuales, pero autoriza a aumentar la pena en un grado "en casos especialmente graves en atención al monto del perjuicio"48. Estimamos que en esta propuesta normativa, ese perjuicio sólo puede referirse al erario de las instituciones públicas indicadas en la misma norma, tanto por los términos en que está redactada, como porque, de haberse referido al patrimonio particular, no habría salido del ámbito de la estafa y otras defraudaciones -como acontece en la actualidad-, para ubicarse en un título destinado a los Delitos contra la Propiedad Intelectual, Industrial, El Sistema Financiero y Otros Intereses Económicos, cuyo carácter colectivo es bastante evidente ${ }^{49}$.

\section{Los delitos aduaneros.}

Por su parte, la tesis según la cual lo protegido por estos delitos es el patrimonio público puede encontrar respaldo en los siguientes argumentos: en primer lugar, en la actual formulación del artículo 168 de la Ordenanza de Aduanas que, al señalar las conductas constitutivas del delito de contrabando, indica, en su inciso tercero, que también comete este delito: "el que, al introducir al territorio de la República, o al extraer de él, mercancías de lícito comercio, defraude a la Hacienda Pública" ${ }^{50}$ mediante la evasión del

\footnotetext{
${ }^{48}$ Artículo 336 del Anteproyecto de Código Penal Chileno de 2005, elaborado por la Comisión Foro Penal. Polit. crim. No 1, D1, pp. 1-92.

${ }^{49}$ En todo caso, haber mantenido la figura en su actual ubicación tampoco habría impedido sostener que lo protegido es el patrimonio público, como acontece en Alemania, legislación en la cual, pese a considerarse una estafa especial, nadie dudaría que el interés tutelado por este delito son los intereses patrimoniales del Estado. En esa línea, KindhäUsER, Urs, Strafrecht. Besonderer Teil II (Baden-Baden, Nomos, 2005), p. 239 y Rengier, Rudolf, Strafrecht. Besonderer Teil (München, Beck, 2000), I, p. 229.

${ }^{50}$ En la tramitación del proyecto de ley que estableciera normas para combatir la
} 
pago de los tributos que pudieren corresponderle o mediante la no presentación de las mismas a la Aduana". Esta norma, fuera de contener una mención expresa al interés tutelado por los delitos aduaneros, esto es, la Hacienda Pública, introduce en nuestra legislación un concepto propio del Derecho español, cuya consagración puede dar pie a múltiples interpretaciones. Así, podría señalarse, que el hecho de que se contemple en la definición del contrabando, dentro de las disposiciones generales relativas a las infracciones a la Ordenanza, obedece a un intento del legislador por incorporar en la legislación penal aduanera la tesis patrimonial, que entiende que lo protegido por este grupo de delitos son los intereses patrimoniales del Fisco $^{51}$. En contra, podría sostenerse que ésta es una norma especial, consagrada en la Ordenanza de Aduanas a propósito de un específico delito: el contrabando; y que su inclusión, en una sola disposición, obedece a un mero capricho del legislador, que en parte alguna establece elementos que permitan definir los contornos de este supuesto interés ${ }^{52}$.

En segundo lugar, en el inciso octavo del artículo 178 de la Ordenanza de Aduanas, según el cual deberá considerarse como circunstancia atenuante calificada, siempre que ocurra antes del acto de fiscalización,

evasión tributaria y culminara con la incorporación, en la Ordenanza de Aduanas, de la noción de Hacienda Pública como interés tutelado, el Informe de la Comisión de Constitución, Legislación, Justicia y Reglamento destacó que el delito de contrabando respondía en su esencia a un tipo defraudatorio, pero que en su actual descripción no se consignaba el fraude como elemento del tipo, "lo que ha llevado a debatir si el bien jurídico protegido es la Hacienda Pública o la autoridad aduanera o, como algunos afirman, se trata de una figura pluriofensiva, porque afectaría ambos bienes jurídicos". Informe de la Comisión de Constitución, Legislación, Justicia y Reglamento, en Boletín 2.572-05 (3 de abril de 2001). Por su parte, el Párrafo $8^{\circ}$ del título $12^{\circ}$ del libro II (artículos 331 a 334) del Anteproyecto de Código Penal Chileno de 2005, elaborado por la Comisión Foro Penal. Polít. crim. No 1, D1, pp. 1-92, dedicado al contrabando y otros delitos aduaneros, inmediatamente después de los delitos tributarios, si bien mantiene, en gran parte, la regulación contemplada en la Ordenanza de Aduanas, alude al perjuicio para el Fisco, y no para la Hacienda Pública.

${ }^{51}$ Asimismo, podría decirse que si en estos delitos el bien jurídico es la Hacienda Pública, no obstante la doctrina dominante estime que el control aduanero también es tutelado penalmente, con mayor razón debiese predicarse en materia tributaria, en que la inclusión de otros intereses, como la función tributaria, carece de un respaldo doctrinal mayoritario.

${ }^{52} \mathrm{Si}$ bien ello puede predicarse respecto de la mayoría de las normas que hacen mención expresa al interés protegido, la situación se agrava cuando la formulación del bien jurídico resulta totalmente extrańa a nuestra tradición jurídico-penal. Igualmente, se echa de menos alguna mención, siquiera breve, en la Exposición de Motivos de dicha normativa, que permitiera sostener con mayor propiedad que el bien jurídico protegido es, efectivamente, la Hacienda Pública. 
entre otras, "el pago voluntario de los derechos e impuestos de las mercancias cuestionadas" 53 .

En tercer lugar, en lo establecido en las normas pertinentes de la Ley No 19.806, conocida también como "Normas adecuatorias del sistema legal chileno a la reforma procesal penal" 4 , que reconocen a la autoridad aduanera, dentro del ámbito de su fiscalización, la facultad de ejercer o no la acción penal por el delito de contrabando: en el primer caso, denunciando o presentando querella ante el Ministerio Público y, en el segundo, renunciando a ejercerla "en la medida en que acepte el ofrecimiento del imputado de pagar una cantidad de dinero" que puede llegar hasta una vez el valor de la mercancía, el que se aceptará, teniendo en consideración los hechos y circunstancias de la denuncia, con lo cual, se extingue la acción penal respectiva ${ }^{55}$.

Finalmente, en cuarto lugar, en la normativa procesal penal relativa a la posibilidad de llegar a acuerdos reparatorios, en la línea de lo establecido precedentemente a propósito de los delitos tributarios, acuerdos que no pueden ser menores al mínimo de la multa, sin perjuicio del pago de la tributación correspondiente ${ }^{56}$.

\section{La malversación de caudales públicos.}

A favor de la tesis patrimonialista, según la cual, lo protegido por la malversación es el patrimonio público, se ha esgrimido toda clase de argumentos ${ }^{57}$, partiendo por el hecho de que la pena se gradúe según el monto

${ }^{53}$ El artículo 333 del Anteproyecto de Código Penal Chileno de 2005, elaborado por la Comisión Foro Penal. Polit. crim. № 1, D1, pp. 1-92, establece que no se podrá aplicar la pena de reclusión si se verifica antes del acto de fiscalización, entre otras, "el pago voluntario de los derechos e impuestos de las mercancías cuestionadas"; mientras que el 334 señala que se considerará circunstancia atenuante "el pago de los derechos e impuestos correspondientes posterior a la fiscalización".

${ }^{54} \mathrm{Su}$ artículo 46 introduce modificaciones fundamentales a la Ordenanza de Aduanas y a la Ley Orgánica del Servicio Nacional de Aduanas, armonizándolas con el nuevo procedimiento penal. Dicha ley -aquí, como en sede tributaria-, cambia las reglas relativas a la investigación y juzgamiento de las infracciones aduaneras, antes, de competencia de los Tribunales Aduaneros, que se suprimen, al igual que las atribuciones del Servicio de Aduanas en la investigación de los delitos.

${ }^{55}$ Prado Casas - Elizalde Aldunate, Ordenanza, cit. (n. 34), pp. 153 y 154.

${ }^{56}$ Prado Casas - Elizalde Aldunate, Ordenanza, cit. (n. 34), p. 154.

${ }^{57}$ Aun relativos a los orígenes del término, que se encontrarían en el delito de peculado (peculatus) romano que, en un principio, contemplaba cualquier ataque a la propiedad pública (aerarium), con total independencia de que el sujeto responsable fuera o no servidor público. En esa línea, Castro Moreno, La malversación, cit. (n. 13), p. 36. 
del peculado ${ }^{58}$, o que se determine en función del efectivo reintegro de los caudales o efectos públicos distraídos ${ }^{59}$.

Igualmente, por la circunstancia de que la mayoría de la doctrina entienda que estamos en presencia de un delito especial impropio ${ }^{60}$ (al menos en las modalidades apropiatorias), resultando obvio que deban existir otros tipos que castiguen las mismas conductas sin requerir la cualidad específica del sujeto exigida en la malversación, conductas que tradicionalmente han sido calificadas de apropiación indebida, hurto, etc., esto es, de delitos patrimoniales, lo cual obedece, precisamente, a que la malversación recoge conductas típicas patrimoniales que son elevadas en su penalidad debido a la especial cualificación del sujeto activo (funcionario público) y del objeto material (caudales públicos) ${ }^{61}$. No obstante, si bien ello es efectivo, existen figuras en nuestro Código Penal en que la protección de la función pública resulta innegable, como los artículos 235 inciso $1^{\circ} \mathrm{y}$ 236 primera parte, que exigen un "efectivo daño o entorpecimiento" para la misma. Sin embargo, dicho requisito no sólo se establece exclusivamente respecto de esos tipos, sino que no se contempla a propósito del peculado, para muchos, la figura básica de malversación ${ }^{62}$.

${ }^{58}$ En ese sentido, los artículos 233 y 238 inciso segundo del Código Penal chileno. En cambio, en el Anteproyecto de Código Penal Chileno de 2005, elaborado por la Comisión Foro Penal. Polit. crim. No 1, D1, pp. 1-92, la pena deja de graduarse según el monto del peculado, como se desprende de los artículos 257 ss., evidenciando un cambio en la valoración de las conductas incriminadas.

${ }^{59}$ Así, el artículo 235 del Código Penal chileno. Por su parte, el artículo 257 inciso final del Anteproyecto de Código Penal Chileno de 2005, elaborado por la Comisión Foro Penal. Polit. crim. No 1, D1, pp. 1-92, dispone que: "La pena de reclusión se impondrá en su grado mínimo si los caudales o efectos apropiados son reintegrados con anterioridad a la formalización de la investigación o del requerimiento, en su caso".

${ }^{60}$ Por todos, Rodríguez Collao - Ossandón Widow, Delitos, cit. (n. 3), pp. 375 y 376.

${ }^{61}$ Castro Moreno, La malversación, cit. (n. 13), p. 43.

${ }^{62}$ Así, Castro Moreno, La malversación, cit. (n. 13), p. 49, quien, comentando la legislación espańola, ha dicho: "el argumento puede volverse en contra, si observamos, en relación al tipo agravado de entorpecimiento, que su propia existencia como tal implica que no es necesario para aplicar el tipo básico de peculado propio (432.1 CP.) la concurrencia de dicho daño o entorpecimiento al servicio público. Sin perjuicio de ello, resulta destacable que el inciso tercero del propio artículo 235 de nuestro Código Penal disponga: "Si el uso indebido de los fondos fuere sin daño ni entorpecimiento del servicio público, las penas serán [...]"; así como que la segunda parte del artículo 236 del mismo Código imponga una pena menor (suspensión del empleo en su grado mínimo y no en su grado medio) "si no resultare daño o entorpecimiento" (para el servicio u objeto en que debían emplearse los caudales o efectos). De ahí que Etcheberry, Derecho penal, cit. (n. 35), IV, p. 244, plantee que la figura 
Asimismo, la protección del patrimonio del Estado puede fundarse en el hecho de que la mayoría de las conductas de malversación recaigan sobre caudales o efectos públicos como objeto material de la acción ${ }^{63}$, a los que se concibe como bienes con contenido patrimonial, susceptibles de apreciación pecuniaria ${ }^{64}$; así como en la circunstancia de que las disposiciones del párrafo que regula este delito se hagan extensivas al que se halle encargado por cualquier concepto de fondos, rentas o efectos municipales o pertenecientes a un establecimiento público de instrucción o beneficencia (artículo 238 inciso primero del Código Penal), dejando en claro que lo que interesa, para efectos penales, es la substracción de "caudales públicos", con entera independencia del sujeto activo que, en caso de ser un particular, no tendrá un deber especial con la Administración, equiparable al del funcionario público ${ }^{65}$.

\section{El fraude al Fisco.}

De todas las figuras que hemos analizado, el fraude al Fisco es la que contiene, en su propia descripción típica, una de las alusiones más claras a la lesión del patrimonio público como interés tutelado, al castigar, en el párrafo $6^{\circ}$ del título $5^{\circ}$ del libro II de nuestro Código Penal, cuyo epígrafe reza: Fraudes y exacciones ilegales, al "empleado público que en las operaciones en que interviniere por razón de su cargo, defraudare o consintiere que se defraude al Estado, a las municipalidades o a los establecimientos públicos de instrucción o de beneficencia ${ }^{266}$. En efecto, el delito que comentamos

de aplicación pública diferente, que corresponde al concepto clásico de malversación, pueda no tener una significación patrimonial para el Estado, sino sólo una incidencia para la buena marcha de su administración económica, y que, en muchos casos, la inversión pública diferente no sólo no lesionará el patrimonio público sino que podrá traducirse incluso en un beneficio económico para el Fisco.

${ }^{63} \mathrm{Y}$ decimos la mayoría, porque existen figuras como el peculado del artículo 233 del Código Penal, que castiga al empleado público que, teniendo a su cargo caudales o efectos públicos o particulares en depósito, consignación o secuestro, los substrajere o consintiere que otro los substraiga.

${ }^{64}$ Así, Etcheberry, Derecho penal, cit. (n. 35), IV, p. 236.

${ }^{65}$ Castro Moreno, La malversación, cit. (n. 13), p. 39.

${ }^{66}$ Esta norma se elimina en el Anteproyecto de Código Penal Chileno de 2005, elaborado por la Comisión Foro Penal. Polít. crim. No 1, D1, pp. 1-92, quedando las figuras protectoras del patrimonio público de la siguiente manera: los delitos tributarios, los delitos aduaneros y el fraude de subvenciones, en el título $13^{\circ}$ del libro II; la malversación y administración desleal de caudales públicos -a la que podría agregarse el tipo de tráfico de influencias-, en el título $11^{\circ} \mathrm{del}$ mismo Libro. 
exige que se produzca un perjuicio ${ }^{67}$, resultado que sólo puede referirse al patrimonio público, tanto por los términos en que aparece redactado, como por la denominación del Párrafo en que se ubica, que opone el concepto de fraude al de exacción ilegal o, lo que es lo mismo, la noción de patrimonio público a la de patrimonio particular ${ }^{68}$.

Asimismo, la protección del patrimonio fiscal puede reflejarse en el castigo que este delito contempla, primero, por hacer depender la pena de multa ${ }^{69}$ del perjuicio causado a las instituciones indicadas y, segundo, porque en comparación con todas las figuras de estafa prevé una pena mayor. Esta circunstancia, que tradicionalmente se ha fundado en que lo tutelado por el fraude al Fisco es, tanto el patrimonio, como la función pública, perfectamente podría interpretarse en el sentido de que lo protegido por el delito es un interés colectivo y no meramente particular, cuya afectación demanda una reacción penal más rigurosa.

\section{DELIMITACIÓN DEL CONCEPTO DE PATRIMONIO DEL ESTADO COMO OBJETO DE TUTELA PENAL}

Si aceptamos que los intereses patrimoniales del Estado se encuentran penalmente protegidos por las figuras a que hemos hecho alusión, si bien con los matices indicados, cabe preguntarse qué significado se atribuye a dicho concepto, teniendo presente que no es unívoco y que los distintos sentidos en que puede utilizarse reflejan entidades estructuralmente muy complejas $^{70}$. En efecto, cuando se hace referencia al patrimonio público puede aludirse, según los casos, a tres realidades distintas: una, de tipo subjetivo, que lo identifica con un ente público; otra, de índole objetiva, que corresponde a cierta clase de bienes o derechos; y una tercera, de carácter funcional, que lo identifica con el desarrollo de cierto tipo de actividad ${ }^{71}$. Veamos en qué consiste cada una de ellas.

${ }^{67}$ Rodríguez Collao - Ossandón Widow, Delitos, cit. (n. 3), p. 401.

${ }^{68}$ En ese orden de ideas, Donna, Edgardo Alberto, Derecho penal. Parte especial (Buenos Aires, Rubinzal-Culzoni, 2003), II-B, p. 336-338.

${ }^{69}$ En cambio, a diferencia de la estafa, aquí no se gradúa la pena privativa de libertad en atención al monto de lo defraudado, sino que se establece una pena única de presidio menor en sus grados medio a máximo.

${ }^{70}$ Gracia Martín, Luis, Las infracciones de deberes contables y registrales tributarios en Derecho penal (Madrid, Trivium, 1990), pp. 75 ss.

${ }^{71}$ Sainz De Bujanda, Fernando, Sistema de Derecho Financiero (Madrid, Facultad de Derecho de la Universidad Complutense, 1977), I, pp. 22 y 23. En esa línea, Ferreiro Lapatza, Curso, cit. (n. 47), pp. 17 y 18, sólo que distinguiendo el sentido subjetivo del objetivo y, en el segundo, el estático y patrimonial -los bienes- del dinámico -la actividad financiera-. 


\section{El patrimonio público en sentido subjetivo.}

En este sentido, el patrimonio público toma el nombre de hacienda, y alude al sujeto de Derecho encargado de obtener ingresos para dotar al Estado de los medios económicos que requiere para alcanzar sus fines, esto es, al titular de una serie de potestades que le otorgan la capacidad de exigir tributos y que, como parte de la Administración Pública, sirve con objetividad los intereses generales ${ }^{72}$. La Hacienda Pública, en esta vertiente, alude al Estado y los demás entes públicos en cuanto desarrollan la actividad financiera, es decir, en cuanto obtienen ingresos y realizan gastos, y se identifica con el sujeto pasivo del conjunto de delitos a que nos hemos referido en el presente trabajo ${ }^{73}$. Es, conforme al uso más generalizado de la expresión, aquella parte del aparato estatal que tiene encomendada la realización de ingresos y gastos ${ }^{74}$, aquel segmento de la organización administrativa que tiene la función de recaudar, administrar y disponer de los medios económico-financieros necesarios para el sostenimiento de la organización y actividad administrativa, así como de controlar el uso de los mismos ${ }^{75}$.

En Chile, la recaudación de todos los ingresos del Sector Público es efectuada por el Servicio de Tesorerías (artículo 30 inciso primero del Decreto Ley de Administración Financiera del Estado $)^{76}$, y el ente encargado de dirigir la administración financiera estatal es el Ministerio de Hacien-

${ }^{72}$ Ayala Gómez, Ignacio, El delito de defraudación tributaria: artículo 349 del Código Penal (Madrid, 1988, Civitas), p. 23. Así también se deduciría del artículo 103 de la Constitución Española.

${ }^{73}$ Por todos, Massone Parodi, Pedro, Principios de Derecho Tributario (Valparaíso, Edeval, 1979), p. 312, respecto de los delitos tributarios; y Politoff - Matus Ramírez, Lecciones, cit. (n. 22), p. 498, respecto del fraude al Fisco; si bien, no queda claro si le atribuyen un significado más amplio, comprensivo de todo el aparato estatal, o más restringido, referido exclusivamente a aquel ente encargado de recaudar, administrar y disponer del patrimonio público. De otro lado, no es del todo evidente que se excluya, bajo cualquier circunstancia, la perspectiva subjetiva del concepto de patrimonio público como interés tutelado; más aún, si en obras como la de GRACIA MARTín, Las infracciones, cit. (n. 71), pp. 63-71, se afirma que: "La protección penal se dispensa a la Hacienda, considerada no como un conjunto patrimonial sino como titular de funciones públicas”.

${ }^{74}$ Ferreiro Lapatza, Curso, cit. (n. 47), p. 18.

${ }^{75}$ Fernández De Moya Romero, José Enrique, El patrimonio como recurso financiero de la Hacienda Estatal (Jaén, Universidad de Jaén, 2002), p. 120.

${ }^{76}$ Decreto Ley No 1263, de 1975. En España, el Tesoro Público es la institución que actúa como cajero del sector público, siendo una de sus funciones fundamentales, la de recaudar los derechos (ingresos) y realizar las obligaciones (pagos) del Estado. En esa línea, Corona, Juan - Díaz, Amelia, Introducción a la Hacienda Pública (Barcelona, 2005, Ariel), p. 91. 
da, labor en la que debe tener presente "el mejor uso de los recursos del país, que se traduzca en una mejor calidad de vida para todos los chilenos, especialmente los sectores más postergados y vulnerables"77. Por su parte, corresponde a la Contraloría General de la República fiscalizar el cumplimiento de las disposiciones legales y reglamentarias que rigen la administración de los recursos financieros del Estado y efectuar auditorías para verificar la recaudación, percepción e inversión de sus ingresos y de las entradas propias de los servicios públicos (artículo 52 inciso primero del Decreto Ley de Administración Financiera del Estado), así como llevar la contabilidad de la Nación, establecer los principios y normas contables básicas y los procedimientos por los que debe regirse el sistema de contabilidad gubernamental (artículo 65 inciso primero del Decreto Ley de Administración Financiera del Estado).

\section{El patrimonio público en sentido objetivo ${ }^{78}$.}

Cuando aludimos al sentido objetivo de la voz patrimonio público, como interés tutelado, estamos refiriendo el objeto jurídico de los delitos que afectan los intereses patrimoniales del Estado a cierta clase de bienes o derechos. Desde esta perspectiva, los intereses patrimoniales del Fisco se identificarían con un patrimonio o con un conjunto de elementos patrimoniales ${ }^{79}$, esto es, con el conjunto de bienes y riquezas o con el importe total del haber del Estado ${ }^{80}$. En sentido objetivo, el patrimonio estatal aparece integrado por todos los bienes cuya titularidad ostenta el ente público, sean muebles o inmuebles, corporales o inmateriales, y con independencia de su régimen jurídico-especial, pero caracterizados por su valorabilidad monetaria, que les permite ser concebidos como elementos financieros con los que satisfacer necesidades públicas ${ }^{81}$. Desde este punto de vista, la expresión patrimo nio público corresponde al conjunto de bienes, derechos y obligaciones de titularidad estatal: se alude así al patrimonio del Fisco del mismo modo en que vulgarmente se habla del patrimonio de un particular ${ }^{82}$, si bien,

77 http://www.hacienda.cl/ministerio.php?opc=showDirectContenido\&navegac ion_id=88, sitio visitado el 25 de octubre de 2007.

${ }^{78}$ En la doctrina administrativista, este sentido de la voz "patrimonio público" corresponde a la idea de dominio público o dominio del Estado, forma de propiedad especial, de naturaleza pública, y regida por normas de carácter público: MorilloVelarde Pérez, José Ignacio, Dominio público (Madrid, Editorial Trivium, 1992), pp. 17 ss.

\footnotetext{
${ }^{79}$ Gracia Martín, Las infracciones, cit. (n. 71), pp. 75 ss.

${ }^{80}$ Castro Moreno, La malversación, cit. (n. 13), p. 51.

${ }^{81}$ Fernández De Moya Romero, El patrimonio, cit. (n. 76), pp. 93, 102 y
} 119.

${ }^{82}$ Ferreiro Lapatza, Curso, cit. (n. 47), pp. 17 y 18. A este sentido objetivo 
en este caso, se agrega como elemento de la definición, la función que el mismo cumple en la satisfacción de necesidades colectivas. De ahí que se sostenga que el patrimonio estatal es un conglomerado heterogéneo de bienes y derechos que la Administración Pública y los órganos del Estado necesitan y utilizan para el cumplimiento de sus fines, revistiendo, desde esta perspectiva, un carácter instrumental o medial ${ }^{83}$.

En esa línea, lo que los autores españoles denominan "Hacienda Pública" se identificaría con un conjunto patrimonial, pero no en tanto universalidad jurídica, sino referido a una organización de recursos destinados de modo permanente a un fin determinado ${ }^{84}$. Desde este punto de vista, la Hacienda Pública aparece como un conjunto de medios económicos, en virtud de los cuales, el Estado procede a cubrir el coste de los bienes y servicios que produce y ofrece a la colectividad ${ }^{85}$.

Precisamente, en el ordenamiento jurídico español, esta organización de recursos está consagrada en el artículo 22 de la Ley General Presupuestaria, que señala: "Son derechos económicos de la Hacienda Pública y constituyen el haber de la misma: a) Los tributos, clasificados en impuestos, contribuciones especiales, tasas y exacciones parafiscales ${ }^{86}$; b) Los rendimientos procedentes de su patrimonio; c) Los productos de operaciones de la Deuda Pública; y d) Los demás recursos que obtenga la Hacienda Pública". Como advierte Gracia Martin, dicha norma enumera unos elementos "constitutivos del haber" de la Hacienda Pública ${ }^{87}$, que integran lo que algunos denominan “activo" de la hacienda fiscal ${ }^{88}$. No obstante, aunque la Hacienda Pública

aludiría el artículo 2 de la Ley General Presupuestaria española, al disponer que la Hacienda Pública, a los efectos de esta Ley, "está constituida por el conjunto de derechos y obligaciones de contenido económico cuya titularidad corresponde al Estado o a sus Organismos Autónomos".

${ }^{83}$ Fernández De Moya Romero, El patrimonio, cit. (n. 76), pp. 119 y 322.

${ }^{84}$ Gracia Martín, Las infracciones, cit. (n. 71), pp. 75 ss.

${ }^{85}$ Sainz De Bujanda, Sistema, cit. (n. 72), p. 24.

${ }^{86}$ Impuestos, contribuciones y tasas, son medios para recaudar ingresos públicos. Los ingresos de los entes públicos son derechos económicos, sumas de dinero que el Estado percibe y puede emplear en el logro de sus fines. Cazorla Prieto, Luis María, Derecho Financiero y Tributario, Parte General (Navarra, Aranzadi, 2006), pp. 101 y 102.

${ }^{87}$ Gracia Martín, Las infracciones, cit. (n. 71), pp. 75 ss.

${ }^{88}$ Sainz De Bujanda, Sistema, cit. (n. 72), p. 24. Si bien la Hacienda Pública consta de un activo y de un pasivo, integrado éste por los débitos (obligaciones de pago de dinero) que en el despliegue de sus funciones la Administración Pública contrae, en lo sucesivo, sólo aludiremos al haber de la misma, sentido en que se utiliza el término por parte de quienes adscriben a la tesis de que la Hacienda Pública es el interés tutelado por los delitos tributarios, aduaneros, etc. Así, Magaldi Paternostro, María José, Delitos contra la Hacienda Pública, en Córdoba Roda - García 
está constituida por diversos elementos, siendo los tributos sólo uno de ellos $^{89}$, si bien cuantitativa como cualitativamente, el más importante ${ }^{90}$, todos pueden reconducirse, jurídicamente, a la idea de "derechos", con lo cual, el activo de la misma quedaría integrado por el conjunto de derechos de contenido patrimonial que la hacienda detenta, sean de índole personal (créditos dirigidos a percibir rentas o precios) o real (dominio sobre bienes muebles o inmuebles, o derechos limitados, de goce o garantía, sobre bienes ajenos) ${ }^{91}$.

A nivel local, por su parte, todos los ingresos que percibe el Estado deben reflejarse en un presupuesto que se denominará del Sector Público, sin perjuicio de mantener su carácter regional, sectorial o institucional, y todos los gastos del Estado deben contemplarse en dicho presupuesto (artículo 4 del Decreto Ley de Administración Financiera del Estado). Asimismo, se establece que "los bienes del Estado, por su importancia en el desarrollo económico y social del país, deben ser manejados en forma tal que su control no entrabe la aplicación oportuna de ellos a los fines del Gobierno" y que su eficiente administración hace imperioso contar con un instrumento que permita obtener su óptimo aprovechamiento ${ }^{92}$, instrumento que en nuestro caso es el Decreto Ley No 1.939 de 1977, sobre Adquisición, Administración y Disposición de Bienes del Estado.

\section{El patrimonio público en sentido funcional.}

En este sentido, el patrimonio público alude a la actividad económica que ejercen los diversos órganos de la Administración y, más precisamente, a la actividad financiera estatal, entendida como "la acción de los entes públicos destinada a la obtención de ingresos, mediante los cuales, se nutre el gasto que facilita la satisfacción de necesidades públicas' ${ }^{\prime 3}$. Tal actividad se

Arán, Comentarios al Código Penal. Parte Especial (Barcelona, Marcial Pons, 2004), I, pp. 1178-1179; Martínez IzQuierdo, Severino, El delito fiscal, con legislación y jurisprudencia (Madrid, Rialp, 1989), p. 17; etc.

${ }^{89}$ Gracia Martín, Las infracciones, cit. (n. 71), pp. 75 ss.

${ }^{90}$ Perulles Bassas, Juan José, Manual de Derecho Fiscal. Parte General (Barcelona, Bosch 1961), p. 101. En la misma línea, Kogan Rosenblüt, Olga - Figueroa Araya, Jaime, El delito tributario (Santiago, Imprenta Chile, sin fecha), pp. 3-7, para quienes, derechamente, la fuente de los recursos estatales y de su incremento la han constituido los tributos; y Gracia Martín, Las infracciones, cit. (n. 71), p. 14.

${ }^{91}$ Sainz De Bujanda, Sistema, cit. (n. 72), p. 25.

92 "Exposición de Motivos" del Decreto Ley No 1939 de 1977, sobre Adquisición, Administración y Disposición de Bienes del Estado.

${ }^{93}$ Cazorla Prieto, Derecho, cit. (n. 87), p. 55. En sentido análogo, Corona - Díaz, Introducción, cit. (n. 77), pp. 4 y 5, y Fernández De Moya Romero, El patrimonio, cit. (n. 76), p. 324, para quien, la actividad financiera puede descom- 
caracteriza por el sujeto que la realiza (el Estado y los demás entes públicos); por el objeto sobre el que recae (los ingresos y gastos públicos o, si se quiere, los medios económicos en que éstos se concretan) y por su carácter instrumental $^{94}$, pues, por medio de ella, no se satisfacen de modo directo e inmediato necesidades colectivas, sino que se suministran los medios económicos (gastos públicos) previamente obtenidos (ingresos públicos), para satisfacerlas ${ }^{95}$.

En nuestro ordenamiento jurídico, los criterios a los que debe ajustarse uno y otro proceso del ciclo financiero ingreso-gasto se encuentran en el numeral 20 del artículo 19 de la Constitución Política. En efecto, la primera parte de dicha disposición se refiere a aquel segmento de la actividad financiera dirigida a la obtención de ingresos públicos, al asegurar a todas las personas: "La igual repartición de los tributos en proporción a las rentas $o$ en la progresión o forma que fije la ley, y la igual repartición de las demás cargas públicas", así como que "En ningún caso la ley podrá establecer tributos manifiestamente desproporcionados o injustos". En cambio, los parámetros por los que debe regirse la otra parte de la actividad financiera, esto es, la dirigida a la realización del gasto público, se encuentran en los incisos tercero y cuarto de la norma referida, según los cuales: "Los tributos que se recauden, cualquiera que sea su naturaleza, ingresarán al patrimonio de la Nación y no podrán estar afectos a un destino determinado". Continúa, luego, el Constituyente: "Sin embargo, la ley podrá autorizar que determinados tributos puedan estar afectados a fines propios de la defensa nacional", y "que los que gravan actividades o bienes que tengan una clara identificación regional o local puedan ser aplicados, dentro de los marcos que la misma ley señale, por las autoridades regionales o comunales para el financiamiento de obras de desarrollo".

En consecuencia y, atendido lo expresado ut supra, nos parece que el bien jurídico protegido por los delitos que se han analizado en el presente ha de resultar, necesariamente, de la combinación de las acepciones objetiva y funcional de la expresión patrimonio público recientemente expues$\operatorname{tas}^{96}$, descartando la perspectiva subjetiva a la hora de dotar de contenido

ponerse en tres momentos básicos: 1. La obtención de ingresos; 2. La gestión de estos recursos; y 3 . El gasto que se hace de los mismos para el mantenimiento de los servicios públicos.

${ }^{94}$ Ferreiro Lapatza, Curso, cit. (n. 47), p. 17.

${ }^{95}$ Cazorla Prieto, Derecho, cit. (n. 87), p. 56.

${ }^{96}$ Para Gracia Martín, Las infracciones, cit. (n. 71), p. 12, la rúbrica del título $6^{\circ}$ del libro II del Código Penal español, esto es, Delitos contra la Hacienda Pública, hace referencia a los tres posibles sentidos de este concepto. Con el subjetivo se alude al sujeto pasivo, con el objetivo al bien jurídico protegido y con el funcional a la ratio legis. 
al interés tutelado, cuya inclusión no sólo importaría confundir el sujeto pasivo - un ente público- con el objeto material del delito, sino que implicaría aceptar que estas figuras no afectan ningún bien jurídico, sino sólo intereses de la Administración, vale decir, un bien administrativo ${ }^{97}$.

Ahora bien, decir que el objeto jurídico se identifica exclusivamente con un conjunto de bienes y derechos, sólo que de entidad pública, no parece justificar el castigo penal -y no meramente administrativo- de muchas de estas conductas, ni la creación de un nuevo sistema de tipos legales, diverso del que regula la estafa, la apropiación indebida o la defraudación a alguna Administración Pública ${ }^{98}$. Mientras que sostener que el interés tutelado está constituido únicamente por una actividad administrativa tendiente a la obtención de ingresos públicos, vuelve a reconducirnos a la idea de que lo protegido es una función administrativa, cuya naturaleza no cede por tratarse de una función trascendente, la más importante para el desarrollo de las demás actividades estatales ${ }^{99}$.

De ahí que afirmemos que el bien jurídico comúnmente protegido por este grupo de figuras sea, tanto el patrimonio estatal como la actividad que ejercen los entes públicos tendiente a la obtención de ingresos y a la realización de gastos ${ }^{100}$ para la satisfacción de necesidades colectivas. Los delitos tributarios, el fraude de subvenciones, los delitos aduaneros, la malversación de caudales públicos y el fraude al Fisco ${ }^{101}$ tienen un objeto

${ }^{97}$ Así, García Belsunce, Horacio, Derecho tributario penal (Buenos Aires, Depalma, 1985), p. 295; y ABRALDes, Sandro, La protección al bien jurídico en la reforma a la ley penal tributaria y previsional, en Ilícitos fiscales. Asociación ilícita en materia tributaria (Santa Fe, Rubinzal-Culzoni, 2004), p. 194.

${ }^{98}$ Medrano, Pablo, Delitos tributarios: bien jurídico y tipos legales, en Delitos no Convencionales (Buenos Aires, Edigraf, 1994), pp. 27 y 28.

${ }^{99}$ Gracia Martín, Las infracciones, cit. (n. 71), p. 70. En la misma línea, López BISCAYART, Javier, El agravamiento de los delitos tributarios y la asociación ilícita fiscal, en Ilicitos fiscales. Asociación ilícita en materia tributaria (Santa Fe, Rubinzal-Culzoni 2004), pp. 157 y 158.

${ }^{100}$ Ferreiro Lapatza, Curso, cit. (n. 47), p. 18. En sentido análogo, Ayala GóMEZ, El delito, cit. (n. 73), p. 26.

${ }^{101}$ En cambio, la doctrina mayoritaria, ubica a la malversación y al fraude al Fisco dentro de los delitos contra la función pública -si bien destaca su carácter patrimonial en relación a otros delitos del mismo título- $y$, separadamente, y aun sin ninguna vinculación -como lo demuestra su regulación fuera del Código Penal y su escaso tratamiento por parte de la doctrina- a los delitos tributarios y aduaneros. Por todos, Etcheberry, Alfredo, Derecho penal. Parte especial (Santiago, Editorial Jurídica de Chile, 1997), III, pp. 445 y 446, y (n. 35), IV, pp. 236 ss. Una sistemática similar a la que planteamos efectúa Queralt Jiménez, Joan, Derecho penal español. Parte especial (Barcelona, 1992, Bosch), pp. 441 ss. , que ubica a los delitos fiscales y a la malversación en un mismo apartado, como delitos contra el sistema socioeconómico y, más 
jurídico común, que se identifica con el patrimonio fiscal y la actividad financiera de obtención de ingresos públicos (delitos tributarios y aduaneros) y de realización del gasto público (fraude de subvenciones, malversación y fraude al Fisco $)^{102}$, actividad que dota al Estado y al conjunto de entidades que lo integran, de los medios necesarios para el desarrollo de las funciones que la ley les ha encomendado ${ }^{103}$.

[Recibido el 19 de octubre y aprobado el 22 de noviembre de 2007].

\section{BIBLIOGRAFÍA}

ABRALDES, Sandro, La protección al bien juridico en la reforma a la ley penal tributaria y previsional, en Ilicitos fiscales. Asociación ilícita en materia tributaria (Santa Fe, Rubinzal-Culzoni, 2004).

Actas de la Comisión Redactora del Código Penal.

Anteproyecto de Código Penal Chileno, de 2005, en Polit. crim. № 1, D1.

Aste Mejías, Christian, Curso sobre Derecho y Código Tributario (Santiago, LexisNexis, 2006).

Ayala Gómez, Ignacio, El delito de defraudación tributaria: artículo 349 del Código Penal (Madrid, 1988, Civitas).

Carocca Pérez, Álex, El nuevo sistema procesal penal (Santiago, LexisNexis, 2005).

Castro Moreno, Abraham, La malversación de caudales en el Código Penal de 1995 (Valencia, Tirant lo Blanch, 2001).

Cazorla Prieto, Luis María, Derecho Financiero y Tributario, Parte General (Navarra, Aranzadi, 2006).

Constitución Española.

De La Mata, Norberto - Etxeberria, Xavier, Malversación y lesión del patrimonio público (Barcelona, Bosch 1995).

Decreto Ley No 1.263 de 1975, de Administración Financiera del Estado.

Donna, Edgardo Alberto, Derecho penal. Parte especial (Buenos Aires, RubinzalCulzoni, 2003), II-B.

Etcheberry, Alfredo, Derecho penal. Parte especial (Santiago, Editorial Jurídica de Chile, 1997), III y Iv.

concretamente, contra la Hacienda Pública, en su vertiente de ingresos y gastos.

${ }^{102}$ Gracia Martín, Las infracciones, cit. (n. 71), p. 10. Mientras los delitos tributarios y aduaneros supondrían una lesión (o peligro) de los ingresos públicos, el fraude de subvenciones, la malversación y el fraude al Fisco atentarían contra el gasto estatal.

${ }^{103}$ Ayala Gómez, El delito, cit. (n. 73), p. 29. Para De La Mata, Norberto EtXeberRia, Xavier, Malversación y lesión del patrimonio público (Barcelona, Bosch 1995), p. 115, la potencialidad de la Administración para cumplir los fines que le son propios depende en gran medida del mantenimiento del sustrato patrimonial que se le atribuye. 
Exposición de Motivos" del Decreto Ley No 1939 de 1977, sobre Adquisición, Administración y Disposición de Bienes del Estado.

Fernández De Moya Romero, José Enrique, El patrimonio como recurso financiero de la Hacienda Estatal (Jaén, Universidad de Jaén, 2002).

Ferreiro Lapatza, José Juan, Curso de Derecho Financiero Español (Barcelona, Marcial Pons, 2006).

García Belsunce, Horacio, Derecho tributario penal (Buenos Aires, Depalma, 1985).

Gracia Martín, Luis, Las infracciones de deberes contables y registrales tributarios en Derecho penal (Madrid, Trivium, 1990).

Guzmán Dálbora, José Luis, Estudios y defensas penales (Santiago, LexisNexis, 2005).

Kindhäuser, Urs, Strafrecht. Besonderer Teil II (Baden-Baden, Nomos, 2005).

Kogan Rosenblüt, Olga - Figueroa Araya, Jaime, El delito tributario (Santiago, Imprenta Chile, sin fecha).

López Biscayart, Javier, El agravamiento de los delitos tributarios y la asociación ilícita fiscal, en Ilícitos fiscales. Asociación ilícita en materia tributaria (Santa Fe, Rubinzal-Culzoni 2004).

Magaldi Paternostro, María José, Delitos contra la Hacienda Pública, en Córdoba Roda - García Arán, Comentarios al Código Penal. Parte Especial (Barcelona, Marcial Pons, 2004), I.

Martínez IzQuierdo, Severino, El delito fiscal, con legislación y jurisprudencia (Madrid, Rialp, 1989).

Massone Parodi, Pedro, Principios de Derecho Tributario (Valparaíso, Edeval, 1979).

Medrano, Pablo, Delitos tributarios: bien jurídico y tipos legales, en Delitos no Convencionales (Buenos Aires, Edigraf, 1994).

Montt Oyarzún, Santiago, Dominio público. Estudio de su régimen especial de protección y utilización (Santiago, ConoSur, 2002).

Morillo-Velarde Pérez, José Ignacio, Dominio público (Madrid, Editorial Trivium, 1992).

Muñoz Conde, Francisco, Derecho penal. Parte especial (Valencia,Tirant lo Blanch, 2004).

Perulles Bassas, Juan José, Manual de Derecho Fiscal. Parte General (Barcelona, Bosch 1961).

Politoff, Sergio - Matus, Jean Pierre - Ramírez, María Cecilia, Lecciones de Derecho penal chileno. Parte especial (Santiago, Editorial Jurídica de Chile, 2004).

Prado Casas, Benjamín - Elizalde Aldunate, Ramón, Ordenanza de Aduanas. Anotada, comentada y concordada (Santiago, 2005, LexisNexis).

Queralt Jiménez, Joan, Derecho penal español. Parte especial (Barcelona, 1992, Bosch).

Rengier, Rudolf, Strafrecht. Besonderer Teil (München, Beck, 2000), I.

Rodríguez Collao, Luis - Ossandón Widow, María Magdalena, Delitos contra la función pública (Santiago, Editorial Jurídica de Chile, 2005).

Sainz De Bujanda, Fernando, Sistema de Derecho Financiero (Madrid, Facultad de Derecho de la Universidad Complutense, 1977), I.

Ugalde Prieto, Rodrigo - García Escobar, Jaime, Curso sobre delitos e infracciones tributarias (Santiago, LexisNexis, 2005). 
Vallejos Castro, Eduardo, La prueba en el delito tributario (Santiago, Editorial Jurídico-Tributaria S.A., 1988).

Van Weezel, Alex, Delitos Tributarios (Santiago, Editorial Jurídica de Chile, 2007). 